\title{
INSECT POLLINATORS OF CONFERENCE PEAR (PYRUS COMMUNIS L.) AND THEIR CONTRIBUTION TO FRUIT QUALITY
}

\author{
Michelle. T. Fountain*, Zeus Mateos-Fierro, Bethan Shaw, Phil Brain, Alvaro Delgado \\ NIAB EMR, New Road, East Malling, Kent ME19 6BJ
}

\begin{abstract}
The pear (Pyrus communis L.) cultivar, Conference, is parthenocarpic but misshapes and marketable fruit losses of $6 \%$ at harvest are common. In other studies, insect flower visitors are identified as important for apple quality, but far fewer studies have examined the effects of insects and cross-pollination on pear quality. Using a range of replicated field experiments, this project aimed to determine the; I) biodiversity of pear blossom insect visitors, 2) pollen limitation and fruit quality as a function of distance from the orchard edge and number of insect visitors, and 3 ) importance of cross pollination on fruit quality. A wide range of insects, $>30$ species, visited pear flowers including honey bees, bumble bees, solitary bees and hoverflies. Honey bees were the most frequent visitors, but all guilds, to a greater or lesser extent, made contact with the reproductive parts of the flower. Insect visits resulted in $\sim 10 \%$ higher fruit set. There was no effect of distance from the edge (up to $50 \mathrm{~m}$ ) of orchard on the quality of pears, and no consistent difference in the guild of insects visiting at distances from the orchard boundary. Cross-pollination with the variety Concorde produced better quality Conference fruits. We discuss how pollination of Conference pears could be managed to improve yields of marketable fruit.
\end{abstract}

Keywords: Andrena, Apis, Bombus, parthenocarpic, pollination, fruit

\section{INTRODUCTION}

Pear is the twelfth most productive fruit crop (25.7 million tonnes/year) worldwide (FAOSTAT 20I5) and 25,800 tonnes/year are harvested in the UK alone (mainly; cultivars (cvs.) Conference, Williams Bon Chretien and Doyenne Du Comice). In the UK, Conference represents 81\% of the pear growing area and $85 \%$ of production with a value of $£ I 3$ million in 2015 (DEFRA 20I6). Conference orchards are increasingly planted in intensified systems resulting in higher densities of blossoms/ha with less reliance on polliniser trees (trees that provide pollen and are often a different variety) as demand for non-Conference varieties decreases.

Conference is semi-self-fertile with a natural tendency for parthenocarpy and can set seedless fruits (MAFF 1973; Nyéki \& Soltész 1998a; Deckers \& Schoofs 2002; Quinet \& Jacquemart 2015). However, growing Conference as a single cultivar orchard has potential to reduce fruit set and quality, and cross-pollination could increase numbers of viable seeds producing higher commercial value fruits with a larger, more uniform, shape (Monzón et al. 2004; Stern et al. 2007; Sakamoto et al. 2009).

Intensive commercial Conference orchards often have no, or only one, polliniser variety for cross-pollination. In addition, although many pear cultivars are self-compatible they still require insect pollination (Goldway et al. 2009; Quinet \& Jacquemart 20I5) and produce more and/or better

Received 3 July 2019, accepted 13 October 2019

*Corresponding author: michelle.fountain@emr.ac.uk fruit when cross-pollinated with another cultivar (MAFF 1973; Webster 2002; Stern et al. 2004).

To date, studies of insect visits to apple (Malus), another pome fruit with a similar open flower structure, demonstrate enhanced fruit- and seed-set, fruit size, evenness of shape, and mineral content (Boyle \& Philogene 1983; Goodell \& Thompson 1996; Volz et al. I996; Buccheri \& Di Vaio 2005; Blazek \& Hlusickova 2006; Garibaldi et al. 2013; Garratt et al. 2014; Rader et al. 2016). However, there is less information about key insect pollinators of pear (Pyrus communis, Rosaceae). In comparison to apple, pear flowers earlier in the season and has a lower sugar concentration in the nectar. As a result, there are reportedly six times fewer insect flower visits to pear blossoms (Quinet et al. 2016b) and fruit and seed set decreases with a diminishing number of pollinated styles per flower (Visser \& Verhaegh 1987). Poor pollination could also result from low insect activity and inefficient transfer of pollen, few polliniser trees, incompatible pollen, or an asynchronous flowering period with the polliniser.

Added to this, recent declines in wild and managed pollinating insects (Biesmeijer et al. 2006; Potts et al. 20I0; Carvalheiro et al. 2013) are a concern for $>70 \%$ of world food crops that rely on animal pollinators (Klein et al. 2007; Aizen et al. 2009). Because the proportion of global agricultural production that relies on animal-pollinated plants has nearly doubled in the last 50 years (Aizen et al. 2008), the loss of pollinating insects could have dramatic and potentially irreversible consequences for biodiversity, agriculture, and food security (Meffe 1998; Potts et al. 2010; Sánchez-Bayo \& Wyckhuys 2019). Simultaneously, intensification of fruit orchards is increasing with higher yields per unit area and, hence, more flowers that require pollination. 
This study aimed to quantify the diversity of insect flower visitors and resultant fruit quality. More specifically, using a range of replicated field experiments, this project determined the; I) diversity of pear blossom insect visitors, 2) pollen limitation and fruit quality as a function of distance from the orchard edge and number of insect visitors, and 3 ) importance of cross pollination on fruit quality.

\section{MATERIALS AND METHODS}

1. Diversity of UK pear insect blossom visitors and the effects of distance from perimeter of orchard on fruit quality

\section{a. Insect surveys}

Six pear orchards were surveyed in 2012 and 2016 and 8 pear orchards in 2014 (Table I). All orchards were in Kent in the south-east of England (GPS coordinates; most easterly and westerly longitudes; 0.268475 and I.373 I I6, most northerly and southerly latitudes 5I.39II6I and 50.97860I, respectively). All were conventionally managed, incorporating the use of pesticides and fertilisers, but were highly variable in planting system. Orchards were between I and $4.5 \mathrm{ha}$, and 552 years since planting; planting densities ranged from I403 to 9570 trees per hectare. In 2012 insect visitors on $\mathrm{cv}$. Conference and one other $\mathrm{cv}$, either a Williams or Concorde orchard on each of 3 farms, was surveyed. In the following years, only Conference orchards were surveyed.

Assessments of insect visitors to pear flowers were done in the spring and fruit was harvested in the autumn to measure fruit quality traits. In all years, pear flower visitors were identified to guild; primarily: bumble bees, honey bees, solitary bees and hoverflies. Records were taken of other notable species including, Coccinelidae, and other Diptera. In 2014 and 2016 (Table I), insect contact with the flower centre, as a proxy for the reproductive parts (stigma/stamen), was recorded. To give an indication of the diversity of insects visiting pear flowers, specimens (except honey bees) were collected during sampling, where possible, for identification.

Surveys were done by walking slowly along a tree row within the orchard for a set time (see below) on each visit and recording the arthropods visiting the flowers. In 2012 (I0-I2 April) and 20I4 (2-I I April) each orchard was surveyed twice for I hour; once in the afternoon and once in the morning, on separate, but within 2 days (between 10:00 and I6:00 hours).
In 2016 (I9 April-6 May) four insect flower visitor surveys were done in 6 of the 8 Conference orchards from 20I4. Eight tree rows were labelled in each orchard and individual trees marked at distances of $0,5,20$, and $50 \mathrm{~m}$ from the orchard boundary. The shortest length of an orchard was $\sim 100 \mathrm{~m}$, so we set the maximum distance as $50 \mathrm{~m}$; this was standardized for all orchards. Insect flower visitor diversity was assessed at the sampling distances at each visit by recorders standing adjacent to a marked tree in each row for 5 minutes (between 10:00 and 16:00 hours). The number of flowers visited by individual insects in a single tree per sequence was recorded; the number of visits the insect made was recorded until it flew to a different tree (Quinet et al. 20I6b).

Surveys were only done on days when there was no precipitation. Temperature was recorded with data loggers (USB-502 loggers, inside a Stevenson's screen) deployed in each orchard. Due to the time of year that pear is in flower it was not possible to restrict observations to above $13^{\circ} \mathrm{C}$ with only minimum cloud cover, as is practiced with other pollinator surveys. Surveys were conducted when temperatures were above $10^{\circ} \mathrm{C}$ in low cloud cover and above $14^{\circ} \mathrm{C}$ on cloudier days (Pywell et al. 2005). During each survey round orchards were visited in a random order to account for any bias due to time of day (Rotheray \& Gilbert 201 I).

\section{b. Fruit yield and quality}

Pear flowers are very similar to apple, but more generally, the petals are white. They have five petals and sepals, and five styles and stigmas. Each style results in one locule with two ovules where a successful pollination should produce two seeds per stigma (Nyéki \& Soltész 1996). To determine the impact of flower visitors on fruit yield and quality a number of measurements were taken. In 2012 (Table I), I8 flower trusses were bagged with a PVC mesh bag (mesh size I.2 $\mathrm{mm}^{2}$ ), and 18 trusses left open to insect pollination in a Conference pear orchard at NIAB EMR (National Institute for Agricultural Botany, East Malling Research) (4 April) in Kent, England. The exclusion bags were removed once the fruit had set (petals senesced) and pears harvested on 08 August, approximately I week before commercial harvest. In 2014 (Table I), 20 alternate trees, in one row, and 25 metres from the edge, and in 2016 a tree at 0,5,20 and $50 \mathrm{~m}$ in from the orchard boundary, were tagged in each orchard, where the insect surveys took place. On each of the selected trees three branches were labelled as either supplementary hand

TABLE I. Timeline of research studies; $x$ denotes years that studies were done

\begin{tabular}{|c|c|c|c|c|}
\hline Year & 2012 & 2014 & 2015 & 2016 \\
\hline Insect visitor survey & $\mathrm{x}$ & $\mathrm{x}$ & & $\mathrm{x}$ \\
\hline Fruit quality traits & $\mathrm{x}$ & $x$ & $x$ & $x$ \\
\hline Fruit set & & $x$ & $x$ & \\
\hline Contact of flower centre by insect & & $x$ & & $x$ \\
\hline Distance of insect guilds from orchard edge & & & & $x$ \\
\hline Cross pollination of $\mathrm{cv}$. Conference with other cultivars & & & $x$ & $x$ \\
\hline
\end{tabular}


pollinated, open pollinated or insect excluded (total of 480 inflorescences in 2014 and 576 inflorescences in 2016). For the hand pollination treatment, one inflorescence was hand pollinated using an artist's paintbrush using pollen from dehisced Conference anthers from the same orchard. Pollen was applied on two occasions to each inflorescence to ensure that all flowers received pollen at least once. The open pollinated treatment was left open to wind and insect visits and only the insect excluded treatment branches were covered with the mesh insect exclusion bags; hence only wind and rain permeable.

The numbers of set pears were recorded for each experimental inflorescence in each orchard (Table I). Fruit set was determined by counting number of flowers and set fruit prior to commercial thinning and, again, at harvest, in some years (Table I). All resulting fruits, were harvested; 47 pears in 2012, 408 pears in 2014 and 1353 pears in 2016 (Table I).

Pear quality measurements were taken as either indicators of pollination success (e.g. seed number, fruit shape) or marketability (russet, mass, shape, Brix). Measurements recorded were as follows; maximum diameter and length ( $\mathrm{mm}$, using Vernier callipers), mass (g, Sartorius electronic scales), $\%$ Russet (percentage of the fruit skin that was slightly rough and brownish), misshape score (0 normal shape, I slight twisting, 2 twisting and unsymmetrical, 3 severely misshapen), firmness ( $\mathrm{N}$ using Lloyd Instruments TA PLUS 108436 penetrometer, $8 \mathrm{~mm}$ probe, 20I2, 2014 samples only), soluble solids content (Brix; from the juice of the fruits, using Palette 7 digital refractometer, 2012, 2014 samples only), seed number and dry matter (\%, 2014 and 2016). Fruits were cut in half and numbers of mature and immature seeds counted. A fully developed brown seed was considered mature. A sample of approximately $10 \mathrm{~g}$ of fruit flesh was oven dried and re-weighed to estimate fruit dry matter.

\section{Effects of cross pollination on Conference fruit quality}

Cross pollination studies were done on one row of Conference pear trees in a commercial orchard at NIAB EMR in 2015 and 2016 (Table I). The orchard, planted in 2009, contained polliniser trees of $\mathrm{cv}$. Verdi at a ratio of $\mathrm{I}: \mathrm{I} 4$ Verdi:Conference. The nearest pear orchard was a 'Comice Sweet Sensation' orchard at a distance of $500 \mathrm{~m}$ from the study orchard.

Approximately two weeks before flowering, five or six inflorescences on 20 or I5 replicate trees were assigned in 2015 and 2016, respectively (I00 and 90 inflorescences in each year). The treatments were randomly allocated on the same tree.

Unopened 'donator' pear flowers (balloon stage) were collected into paper bags from commercial orchards or the pear gene bank orchard at NIAB EMR for cross-pollinating the Conference orchard flowers. Anthers were removed from collected flowers and donator pollen left to dehisce in Petri dishes in the laboratory at $20^{\circ} \mathrm{C}$. A sample of each pollen variety was evaluated in 2016 for percentage germination viability (Shivanna \& Rangaswamy 2012). Pollen was tested in-vitro on an agar-sucrose medium supplemented with a trace amount of boric acid (Santos et al. 1996). A pinch of dehisced pollen was poured to form a cloud of pollen over a Petri dish. Pollen was assessed after 24 hours at ambient temperature. One hundred pollen grains were counted using a light microscope and percent pollen germination (PPG) was calculated. The pollen grains were considered germinated when pollen tube length reached pollen diameter.

All flowers on a single truss of a Conference receiver tree were treated with the same pollen variety. Treatments were open pollinated, insect excluded, or Comice, Conference or Concorde cross-pollinated in 2015 and open pollinated, insect excluded, or Conference, Comice, Concorde or Verdi cross-pollinated in 2016. The hand pollinated and pollinator excluded inflorescences were covered with a PVC mesh bag, as above. Because Conference is mostly self-fertile it was necessary to emasculate flowers before applying the donor pollen. This was done at flower 'balloon' stage; both petals and anthers were removed, using fine scissors and forceps, reducing the likelihood of self-pollination. An artist's paintbrush was used to transfer the pollen from the donor pear variety to the receiver Conference flowers by moving the brush across the stigma of the receiving flower. Once the fruit had begun to set (when petals had senesced) the insect exclusion bags were removed from all treatments (except the open pollinated).

Fruit set was determined in 2015 prior to commercial fruit thinning (I5 July) and harvest (I September) following the same methodology, above. All fruits were harvested a week before commercial harvest. Fruit quality measures were done on 335 pears in 2015 and 310 in 2016.

\section{Data analyses}

All analyses were done in Genstat I8 (VSN International 20I5). To avoid possible confusion, we use the notation $A \times$ $B$ to denote the interaction between $A \& B$, and $A * B$ to denote the main effects for $A$ and $B$, and the interaction $A \times B$. Where the fixed model is $A^{*} \mathrm{~B}$ we test the terms $\mathrm{A}, \mathrm{B}, \mathrm{A} \times \mathrm{B}$ separately.

\section{Insect pear blossom visitor data}

The counts of the different for the various Insect visitor guilds (honey bee, bumble bee, Diptera, hoverfly, solitary bee) for 2012 and 2014 were combined for analyses using a generalised linear mixed model (GLMM) with the Poisson distribution and a log link function, and adjusted for overdispersion using a quasi-likelihood approach (McCullagh \& Nelder 1989). The analyses of the 2012 insect counts had Insect Guild Pear variety as fixed effects and the Farm $\times$ Pear Variety $\times$ Insect Guild interaction as the random term. There was no evidence of a pear variety effect or insect $X$ pear variety interaction, so the data was reanalysed omitting pear variety. The analysis of the 2014 insect guild counts had Insect Guild as a fixed term (as this was a single variety study), and the Orchard $\times$ Insect Guild interaction as the random term. Insect counts from 2016 were analysed using a GLM analysis, with the Poisson distribution and a log link function, adjusted for overdispersion. The GLMM model with Orchard $\times$ Distance $\times$ Insect Guild as a random effect did not converge, implying 
that this term was not significant. The fixed terms were Insect Guild Distance ${ }^{*}$ Treatment.

Pairwise treatments were tested using appropriate contrasts within the analysis of deviance tables, hence were employing one degree of freedom likelihood ratio tests (Brain $\& \mathrm{Xu}$, in prep. as used in Shaw et al. 2019). Significances were quantified using either the F-distribution (where overdispersion was present), or the Chi-squared distribution (where there was no evidence of overdispersion). We refer to this as the "likelihood ratio test" approach. This was instead of approximate t-tests that are based on the differences between the estimated means with SED's obtained from the variance-covariance matrix. For means near the boundary (near 0, for the Poisson; near 0 and 100 for the binomial distribution), this can give incorrect significances; the "likelihood ratio test" approach, described above, avoids this problem.

Insect guilds with fewer than 10 visits total (e.g. ants, weevils, caterpillars, spiders, pollen beetles, sawfly, anthocorids and earwigs) were removed from the statistical analysis.

\section{Contact with centre of flower}

The proportion of the insects from guilds (honey bee, bumble bee, Diptera, hoverfly, solitary bee) that made contact with the centre of the flower in $2014 \& 2016$ was analysed using a GLM with a binomial distribution, logit link function, and Orchard and Insect as fixed effects. Pairwise significant differences were tested as for the insect visitor data. As there was no overdispersion and the significances are quantified using the Chi-squared distribution.

\section{Fruit quality}

Fruit set in 2014 and 2015 was analysed using a GLMM with fixed effects being Orchard + Treatment and random effects being the Orchard $\times$ Treatment interaction. Pairwise significance tests were carried out using the "likelihood ratio test" approach.

All fruit quality measures were normally distributed. For 2012 the fruit quality measures were analysed using ANOVA with Treatment as the fixed effect and no random effects. For 2014 the unbalanced nature of the design necessitated analyses using linear mixed effects models with fixed effects being Orchard and Treatment and random effects being Trees nested within Orchards. The model was fitted using restricted maximum likelihood (REML). For 2016 the fruit quality measurements were again analysed using a linear mixed effect model with the fixed effects being Orchard + Treatment ${ }^{*}$ Distance ${ }^{*}$ Insect exclusion and random effects being Insect exclusion within Distance within Row within Orchard. Pairwise comparisons were done using t-tests based on the means and SED's from the analysis.

\section{Cross pollination}

For both 2015 and 2016 fruit quality data was analysed using linear mixed effects models. The fixed effects model was Block (individual tree) + Treatment and the random effects Block $\times$ Treatment. It was not necessary to transform data as there was no evidence of non-normality.

\section{RESULTS}

\section{Diversity of UK pear insect blossom visitors and the effects of distance from perimeter of orchard on fruit quality}

Insect visit observations totalled 480 (2012 and 20I4) and 3840 (2016) minutes. The number of insect visits to a pear blossom were $2 \mathrm{I} 5(0.6 / \mathrm{m}), 4 \mathrm{I} 3(0.86 / \mathrm{m})$ and $\mathrm{I} 478$ $(0.64 / \mathrm{m})$ for 2012, 2014 and 2016, respectively. Overall, honey bees were the dominant visitors of pear flowers in all 3 years. In addition, honey bees and solitary bees made contact with the reproductive parts of the flower structure (flower centre) more frequently; for example, insects which alighted on the petals only, were considered not to be in contact with the reproductive parts of the flowers.

More than 30 species were identified with some commonalities between years (Table 2). Hoverfly species assemblages were variable between years, however 3 Andrena species were common in all years ( $A$. haemorthoa, $A$. nigroaenea and $A$. nitida), and 3-4 Bombus species ( $B$. terrestris/lucorum, B. lapidarius and B. pascuorum) in years 2014 and 2016 (Table 2).

In 2012 and 2016, more honey bees visited pear flowers compared to all other blossom visitors, except solitary bees in 2012 (Fig. I, $\mathrm{HB}$ vs $\mathrm{SB}, P=0.237, \mathrm{~F}_{1,31}=1.506$; all other comparisons vs $\left.\mathrm{HB} ; P<0.013 ; \mathrm{F}_{\mathrm{I}, 31}>7.179\right)$. In 2014 similar numbers of honey bees, bumble bees, hoverflies, and other Diptera visited flowers; however honey bee visits exceeded those of solitary bees $\left(P=0.006 ; \mathrm{F}_{1,31}=8.078\right)$, Vespula $\left(P=0.002 ; \mathrm{F}_{1,31}=10.684\right)$ and Coccinelidae $(P=$ $\left.0.03 \mathrm{I} ; \mathrm{F}_{1,31}=4.985\right)$.

Over $95 \%$ of honey bees, and 65 to greater than $90 \%$ of solitary bees, made contact with the centre (Fig. 2) of pear flowers and, more so than hoverflies, bumble bees, Vespula, Coccinelidae and other Diptera (Fig. 2; 20I4; $P<4 \mathrm{e}-7$, ChiSquared (I d.f.) $>25.402 ; 2016 ; P<0.022$; Chi-Squared (I d.f.) $>5.282$ ). Over $60 \%$ and $90 \%$ of bumble bees, in 2014 and 2016, respectively, made contact with the flower centre. This was followed by hoverflies, Vespula, Coccinelidae and other Diptera.

The numbers of insect flower visitors in 6 orchards, foraging at different distances $(0,5,20$ and $50 \mathrm{~m})$ from the orchard edge, was assessed in 2016. There was no effect of foraging distance from orchard edge on solitary bees, Coccinelidae or Vespula. There were significantly higher numbers of honey bees $20 \mathrm{~m}$ in from the orchard edge $(P<$ $0.00 \mathrm{I} ; \mathrm{F}_{1,2820}=32.104$ ) fewer foraging $5 \mathrm{~m}$ in from the edge $\left(P=0.006 ; \mathrm{F}_{1,2820}=68.773\right.$, Fig. 3$)$. Honey bees were also significantly fewer at $50 \mathrm{~m}$ compared to $20 \mathrm{~m}(P<0.00 \mathrm{I}$; $\left.\mathrm{F}_{1,2820}=35.755\right)$. In contrast there were significantly fewer bumble bees visiting pear blossoms at $20 \mathrm{~m}$ compared to the edge of the orchard ( 0 vs $20 P=0.0 \mathrm{I}, \mathrm{F}_{1,2820}=6.597 ; 5$ vs 20 $\left.P<0.001, \mathrm{~F}_{1,2820}=\mathrm{I} 3.007\right)$.

Higher numbers of hoverflies and other Diptera foraged closer to the orchard edge (0-5 m) compared to $20-50 \mathrm{~m}$ (hoverflies; $P=0.017 ; \mathrm{F}_{1,2820}=5.69(0$ vs $20 \mathrm{~m})$, Diptera; $P$ $=0.008 ; \mathrm{F}_{\mathrm{I}, 2820}=7.030(0$ vs $20 \mathrm{~m}) ; P=0.002 ; \mathrm{F}_{\mathrm{I}, 2820}=$ 10.058 (0 vs $50 \mathrm{~m})$ ). 


\section{Fruit quality}

In 2012 there was no evidence of differences between the insect excluded (E) and the open $(\mathrm{O})$ pollination treatments for mean fruit circumference $(45.8 \mathrm{~mm})$, length $(96.3 \mathrm{~mm})$, mass (82.5 g), russet (66.6\%), Brix (I0.6), or firmness (I04.I N) (compared using t-tests). However, the fruit misshape score was significantly higher in fruits not visited by insects ( 1.78 compared to I.I7, $P=0.041, \mathrm{t}_{45}=2.107$ ) and numbers of mature seeds were higher in fruit visited by insects (5.72 compared to I.6I, $P<0.001$, $\mathrm{t}_{45}=3.986$ ).

TABLE 2. Species list of insect flower visitors to pear blossom identified in 2012, 2014 and 2016. X indicates an observation in that year.

\begin{tabular}{|c|c|c|c|c|}
\hline Genus & Species & 2012 & 2014 & 2016 \\
\hline Apis & mellifera & $\mathrm{X}$ & $\mathrm{X}$ & $\mathrm{X}$ \\
\hline \multirow[t]{11}{*}{ Andrena } & dorsata & $\mathrm{X}$ & $\mathrm{X}$ & \\
\hline & labialis & & $\mathrm{X}$ & \\
\hline & fulva & & $\mathrm{X}$ & \\
\hline & haemorthoa & $\mathrm{X}$ & $\mathrm{X}$ & $\mathrm{X}$ \\
\hline & nigroaenea & $\mathrm{X}$ & $\mathrm{X}$ & $\mathrm{X}$ \\
\hline & nitida & $\mathrm{X}$ & $\mathrm{X}$ & $\mathrm{X}$ \\
\hline & minutula & $\mathrm{X}$ & & $\mathrm{X}$ \\
\hline & chrysosceles & & & $\mathrm{X}$ \\
\hline & flavipes & $\mathrm{X}$ & & \\
\hline & synadelpha & $\mathrm{X}$ & & \\
\hline & scotica & $\mathrm{X}$ & & $\mathrm{X}$ \\
\hline Lasioglossum & calceatum & & & $\mathrm{X}$ \\
\hline Halictus & $s p$ & & & $\mathrm{X}$ \\
\hline \multirow[t]{4}{*}{ Bombus } & terrestris/lucorum & $\mathrm{X}$ & $\mathrm{X}$ & $\mathrm{X}$ \\
\hline & lapidarius & & $\mathrm{X}$ & $\mathrm{X}$ \\
\hline & pascuorum & $\mathrm{X}$ & $\mathrm{X}$ & $\mathrm{X}$ \\
\hline & hypnorum & & & $\mathrm{X}$ \\
\hline Vespula & germanica & & $\mathrm{X}$ & \\
\hline Episyrphus & balteatus & & & $\mathrm{X}$ \\
\hline Syrphus & ribesii & & $\mathrm{X}$ & \\
\hline \multirow[t]{2}{*}{ Eupeodes } & corollae & & & $\mathrm{X}$ \\
\hline & luniger & & & $\mathrm{X}$ \\
\hline Epistrophe & eligans & $\mathrm{X}$ & & \\
\hline \multirow[t]{2}{*}{ Melanostoma } & mellinum & & & $\mathrm{X}$ \\
\hline & scalare & $\mathrm{X}$ & & \\
\hline \multirow[t]{4}{*}{ Platycheirus } & angustatus & & $\mathrm{X}$ & \\
\hline & albimanus & & & $\mathrm{X}$ \\
\hline & peltatus & $\mathrm{X}$ & & $\mathrm{X}$ \\
\hline & scutatus & & & $\mathrm{X}$ \\
\hline \multirow[t]{2}{*}{ Eristalis } & arbustorum & $\mathrm{X}$ & & \\
\hline & pertinax & & $\mathrm{X}$ & \\
\hline Helophilus & pendulus & & $\mathrm{X}$ & \\
\hline
\end{tabular}

In 2014 mean $( \pm \mathrm{SE})$ fruit set in insect $\mathrm{E}$ treatment $(24.9 \% \pm 2.3)$ was lower than hand $(\mathrm{H})(35.7 \% \pm 2.4$ Conference cross) or O pollinated $(35.5 \% \pm 2.5)$ treatments at harvest $\left(P=0.027 ; \mathrm{F}_{1,12}=6.099\right)$, and $\left(P=0.015 ; \mathrm{F}_{1,14}=\right.$ $7.701)$, respectively.

There was no difference among treatments for fruit quality measures (means) taken in 20I4, including; circumference ( $59.9 \mathrm{~mm}$ ), length (I0.7 mm), mass (I48.6 g), russet $(3.8 \%)$, Brix (I I.4), firmness $(66.5 \mathrm{~N})$, dry matter (I5.I \%), shape score (I.2) and total numbers of seeds (6.4/fruit). However, there were significantly more mature seeds in $\mathrm{O}$ compared to $\mathrm{E}$ pear fruits (means; E 0.000, H 0.169, $\mathrm{O} 0.245, P=0.010, \mathrm{t}_{151}=2.6 \mathrm{I} 7$ ).

In 2016, fruit quality data was analysed for several independent variables: pollination treatment $(\mathrm{E}, \mathrm{O}$ or $\mathrm{H})$ and distance from the orchard edge. Only pollination treatment influenced some fruit quality traits; usually a reduction in fruit quality measures in flowers previously excluded from insect visits. There were no differences in fruit length (I02.8 mm), russet $(71.5 \%)$ or dry matter content (16.1\%). However, there were more misshapen fruits in the $\mathrm{E}$ treatment $((\mathrm{E}$ I.554, H I.I54, O I.062), (E vs H, E vs O; $P<0.001$, t258 $=5.888 \& 7.28 \mathrm{I}$, respectively), and fruits were wider $(\mathrm{E}$ 53.39, H 52.93, O $54.58 \mathrm{~mm}$ ) where in the $\mathrm{O}$ treatment $(\mathrm{O}$ vs E, $P=0.02 \mathrm{I}, \mathrm{t}_{250}=2.333 ; \mathrm{O}$ vs $\mathrm{H}, P=0.00 \mathrm{I}, \mathrm{t}_{250}=$ 3.293), and heavier (E I24.4, H II9.8, O I28.7 g) in O compared to $\mathrm{H}(\mathrm{O}$ vs $\mathrm{H}, P=0.008$, t250 $=2.676)$ treatment. Significantly higher numbers of mature seeds (E 0.128, H 0.408 , O 0.600), and total numbers of seeds (E 6.59I, H 7.526, 07.477$)$ per fruit were observed in $\mathrm{O}$ compared to the E treatment (O vs E, $P=0.003$, $\mathrm{t}_{250}=3.004 ; P<0.001$, $\mathrm{t}_{250}=4.06 \mathrm{I}$, respectively). Total numbers of seeds were also higher in $\mathrm{H}$ compared to the $\mathrm{E}$ treatments ( $\mathrm{H}$ vs $\mathrm{E}, P<0.00 \mathrm{I}$, $\left.\mathrm{t}_{250}=4.24 \mathrm{I}\right)$.

\section{Effects of cross pollination on Conference fruit quality}

At the study site, in 2015 and 2016, cv. Comice (Sweet Sensation) trees flowered almost a week later than Conference trees. This was in agreement with pear flowering records of the UK National Fruit Collection (NFC) in south-east England. The 40-year mean of full bloom was predicted as I5 April in Conference, 27 April on Doyenne du Comice, and 17 April for Concorde. For pollen to be considered viable the industry's acceptable germination value is $>25 \%$ germination (Santos et al. 1996). In 2016 the donor cvs. Concorde, Comice, Verdi, and Conference had germination rates of 79, 57,56 , and $44 \%$ respectively. Pollen was not tested in 2015.

In 2015, pollination treatment had a significant effect on overall fruit shape score $(P<0.00 \mathrm{I})$, width $(P<0.00 \mathrm{I})$, weight $(P=0.006)$, firmness $(P=0.002)$, and numbers of mature seeds $(P=0.017$, Fig. 4A). Pear russet $(P=0.322)$, height $(P=0.10 \mathrm{I})$, Brix $(P=0.275)$, and total numbers of seeds $(P=0.174)$ did not differ between pollination treatments. Fruits that were excluded from hand or insect pollination had a poorer shape than all other treatments $(P<$ 


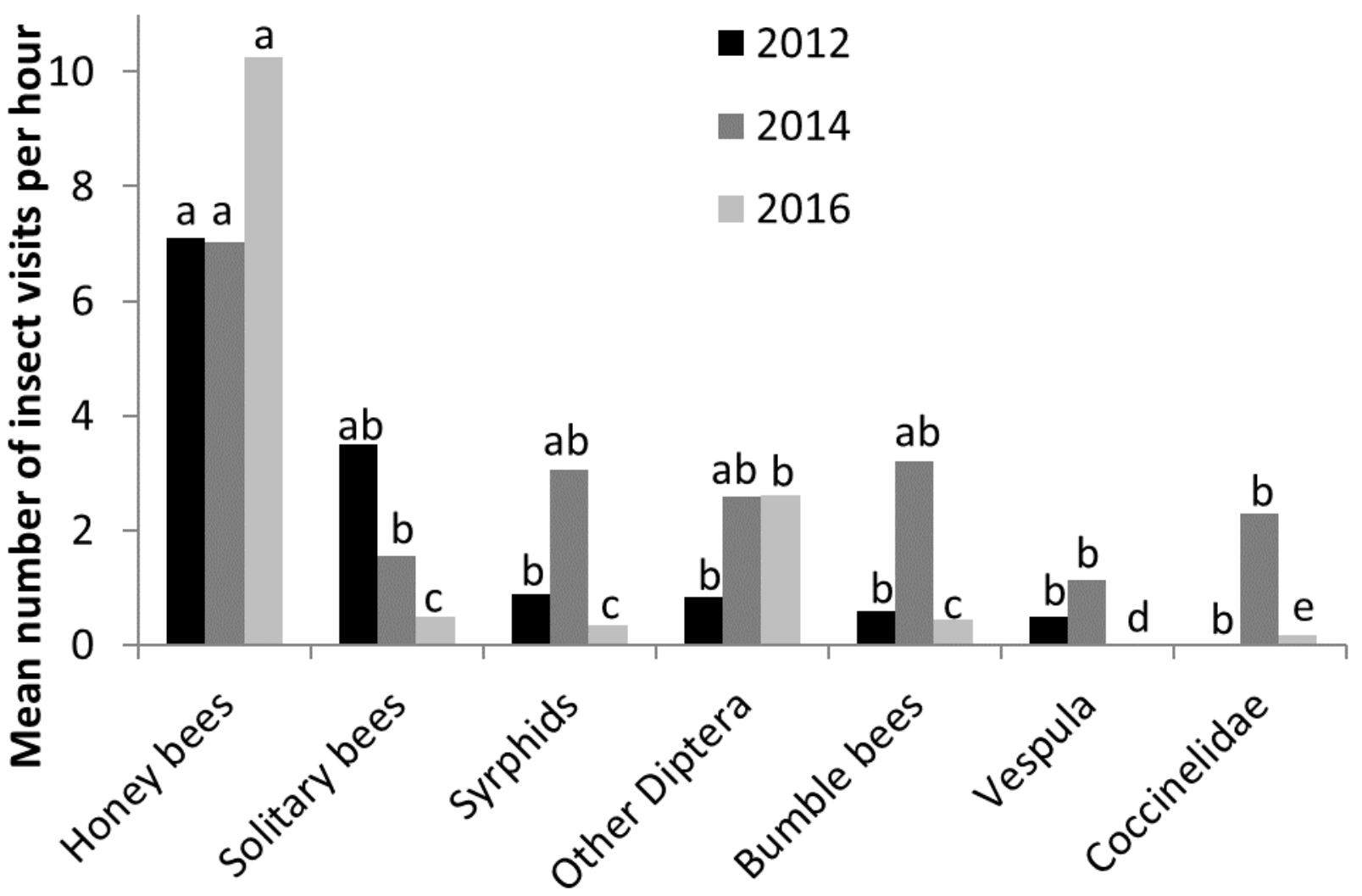

FIGURE I. Mean number of insect visits (Syrphids = hoverflies) per hour to pear flowers in 2012, 2014 and 2016 in 6, 8, and 6 pear orchards, respectively. Letters show statistical differences between insect visitors within each year

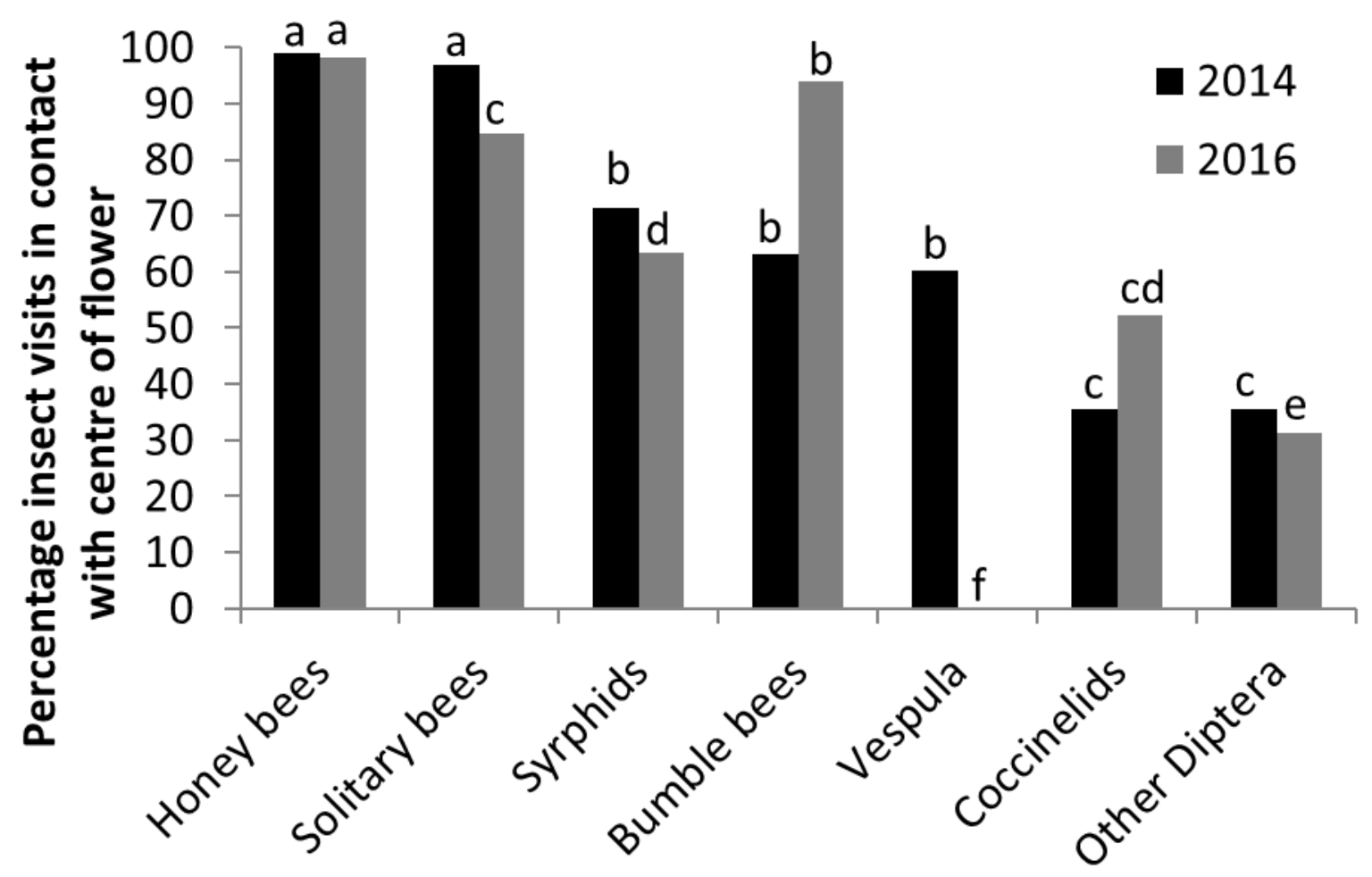

FIGURE 2. Mean percentage of insect visitors making contact with the centre of pear flowers (assessments in 2014 and 2016 in 8 , and 6 pear orchards, respectively). Letters show statistical differences between insect visitors within each year 


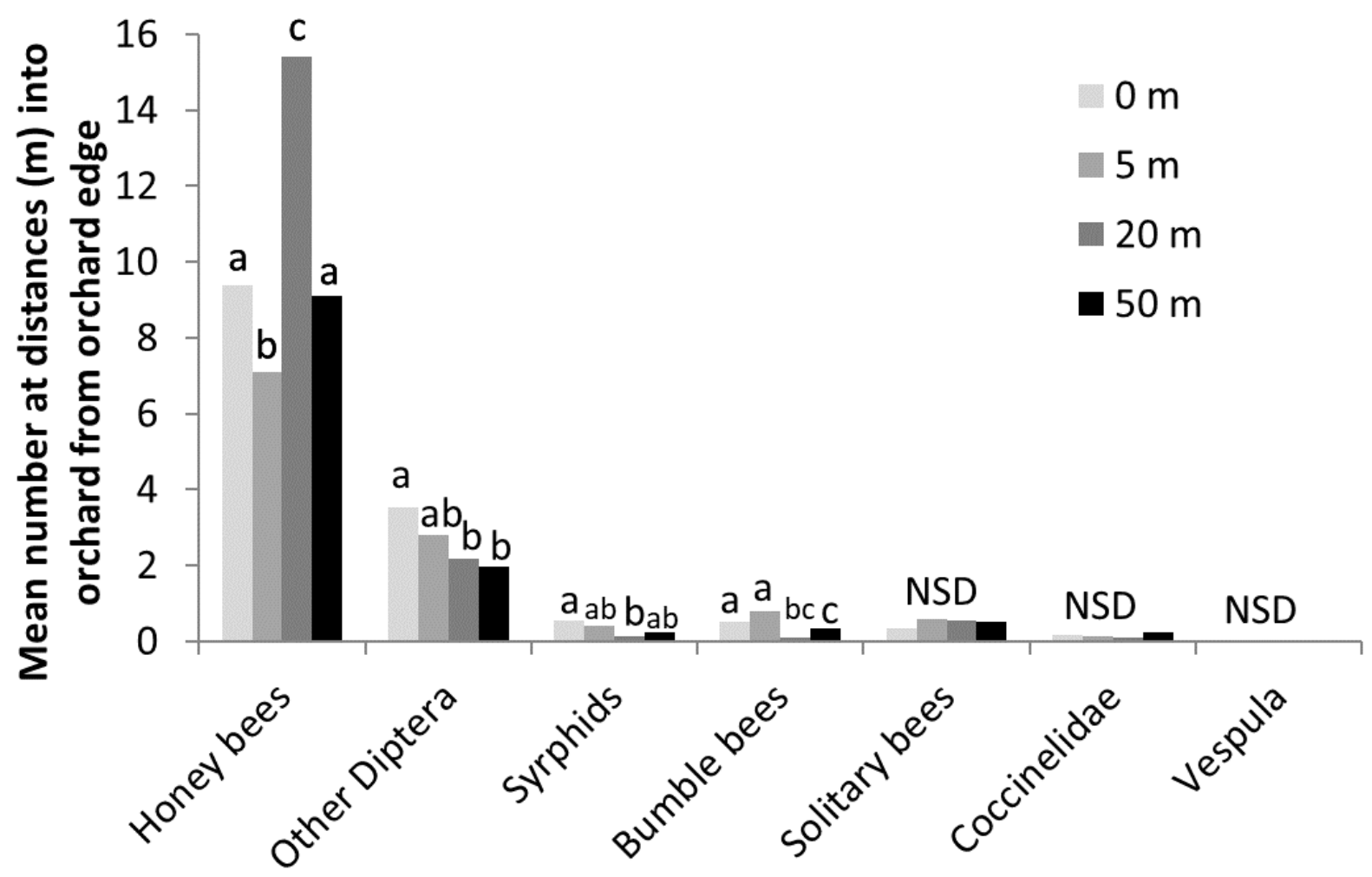

FIGURE 3. Mean numbers of insect visitors per hour to pear flowers at different distances into pear orchards from the orchard edge in 2016. Letters show statistical differences between distances for each insect group. NSD $=$ no significant difference.

0.017, t52 > 2.456). Conference fruits pollinated with Concorde pollen had better shape than Conference $(P=$ $\left.0.020, \mathrm{t}_{52}=2.394\right)$ or Comice $\left(P=0.019, \mathrm{t}_{52}=2.432\right)$ pollinated fruit, but did not differ from open pollinated fruit, which had an unknown pollination source (Fig. 4A). In addition, fruits pollinated with Concorde or Comice were wider and had a greater mass than Conference pollinated, insect excluded, or open pollinated fruits (width; $P<0.038$; $\mathrm{t}_{52}>2.134$, Fig. 4B; weight, $P<0.020$, t52 $>2.122$, Fig. $4 \mathrm{C}$ ). Comice or Concorde hand pollinated fruits were $>\mathrm{I} 4 \mathrm{~g}$ heavier and $3.4 \mathrm{~mm}$ wider than Conference pollinated fruits.

Insect pollinated (presumably predominantly Verdi and/or Conference pollen, I2I.9 g) or flowers excluded from insects ( $120.3 \mathrm{~g}$ ) were approximately the same weight and diameter as Conference hand pollinated fruits (I22.5 g).

Fruit firmness was higher in Conference $\times$ Conference treatments $(P<0.037$, t52 $>2.138$ Fig. 4D), and numbers of mature seeds was low (usually fewer than I.2 mature seeds per fruit). However, higher numbers of mature seeds were recorded with Concorde pollination compared to Conference and insect excluded treatments $\left(P<0.004, \mathrm{t}_{52}>2.989\right.$ Fig. $4 \mathrm{E}$ ). Comice and open treatments had similar numbers of mature seeds to Concorde pollinated fruits. Although there was no overall difference in dry matter, insect excluded pears had lower dry matter than open pollinated pears $(P=0.032$, $\mathrm{t}_{52}=2.197$, Fig. $4 \mathrm{~F}$ ).

In 2016 (comparing open, insect excluded, Conference, Comice, Concorde or Verdi pollination) there were no overall differences in fruit russet, height, width, weight, number of mature seeds, nor numbers of total seeds. However, there were more misshaped fruits in the insect excluded treatment compared to all other treatments, except Comice pollinated ( $P$ $<0.019, \mathrm{t}_{52}>2.253$, Fig. 5A). Open pollinated fruits had better shape in 2016, but only significantly better than insect excluded $\left(P<0.001, \mathrm{t}_{52}=3.948\right)$, and Comice pollinated fruits $\left(P=0.029, \mathrm{t}_{52}=2.253\right)$. There was evidence of higher mature seed numbers in Concorde pollinated compared to Conference $\left(P=0.048, \mathrm{t}_{52}=2.029\right)$ and insect excluded fruits $(P=0.023$, t52 $=2.348$, Fig. $5 \mathrm{~B})$.

\section{DISCUSSION}

The general aim of this study was to quantify the diversity of insect flower visitors and resultant fruit quality. More specifically, using a range of replicated field experiments we demonstrated; firstly, pear blossoms are visited by a range of insects which comprise mostly honey bees ( $\sim 35 \%$ of visitors), then solitary bees, hoverflies and bumble bees. Secondly, the distance from the orchard boundary did not impact the marketable quality of pear fruits in Conference orchards of I.0 and 4.5 ha. Finally, marketable cv. Conference yields could be improved by cross-pollinating with another variety, facilitated by insect visitors.

The main insect blossom visitors also made contact with the centre of the flower and were doubtless significant vectors of pollen between pear flowers (Radar et al. 2016). There was variation in the species of hoverfly visiting the flowers between years even though the same orchards were surveyed, but solitary bees consisted primarily of ground nesting Andrenid 

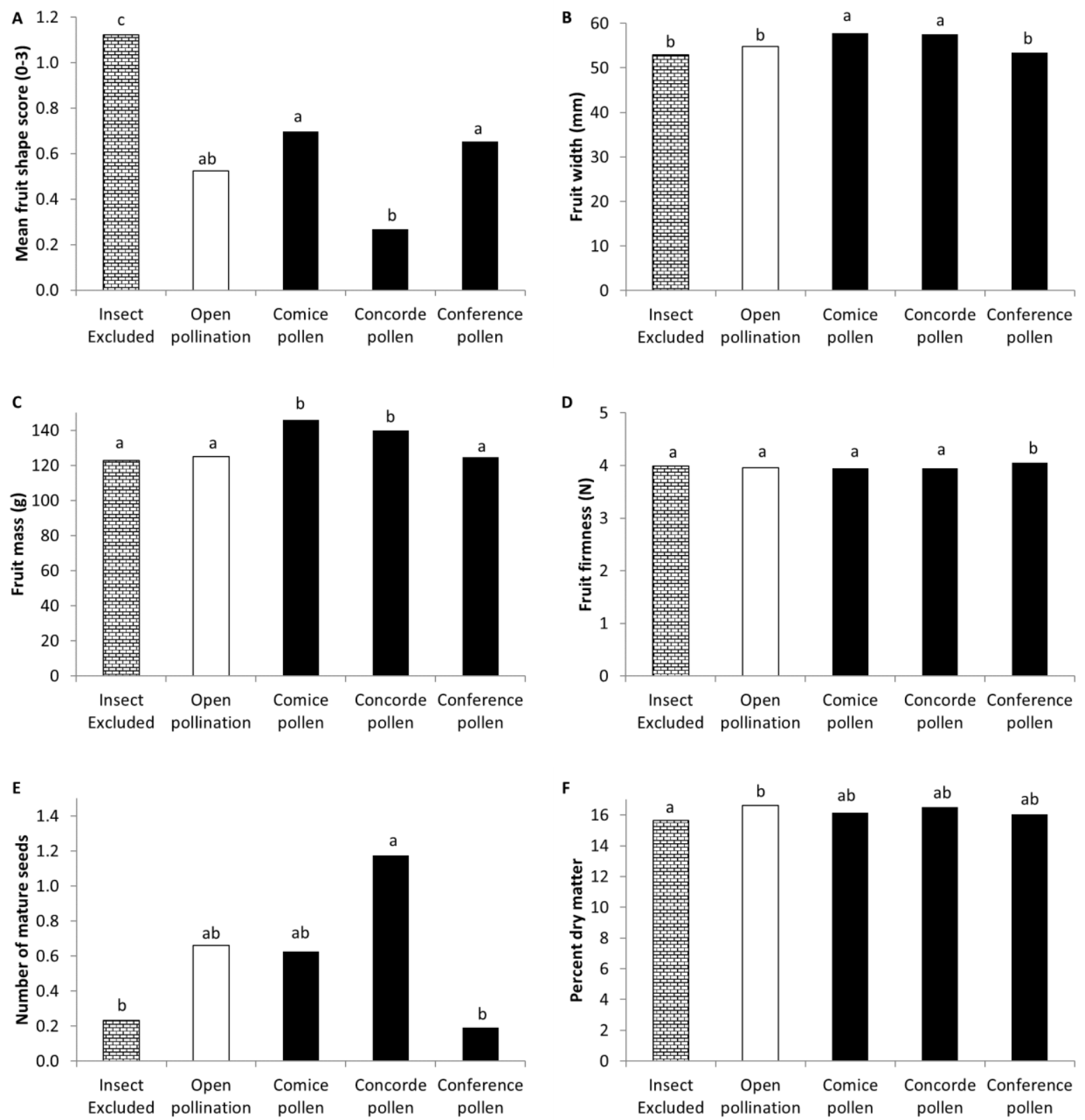

FIGURE 4. Fruit quality measures from Conference flowers open pollinated (by wind and insect visits), insect excluded (wind pollination only) or hand pollinated with either Comice, Concorde or Conference pollen. Mean A) fruit shape score ( 0 normal shape, I slight twisting, 2 twisting and unsymmetrical, 3 severely misshapen), B) fruit width, C) fruit mass, D) fruit firmness, E) number of mature seeds (those which were brown in colour) and percent dry matter in the 2015 experiment.

species; Andrena dorsata and A. haemorrhoa, and bumble bees were also similar between years (B. terrestris/ucorum, $B$. lapidarius and B. pascuorum). Future controlled manipulative cage studies could be employed to determine the contribution that specific insect taxa contribute to pear pollination and fruit quality (Hodgkiss et al. 2018; Garratt et al., 2016).

Numbers of insects visiting pear flowers were fewer than half those visiting apple blossoms (Garratt et al. 2016). This could be due to the earlier flowering period, but honey bees have been recorded moving to other fruit tree species or more attractive plants including Sinapis alba (white mustard) Stellaria spp. (chickweed), Taraxacum officinale (dandelion), in preference to pear, if in flower in the same locality (review in Free, 1993).

A diverse range of insects is thought to contribute to overall pollination, not only from increased abundance, but also a higher frequency of flower visits (Klein et al. 2003, Stern et al. 2004; Rader et al. 2016). As a result, a diverse pollinator assemblage will more effectively pollinate crops (Blitzer et al. 2016), with several studies showing that diversity, rather than just pollinator abundance, enhances seed set (Klein et al. 2003; Hoehn et al. 2008; Mallinger and Gratton 20I5; Martins et al. 2015). Diptera were abundant in our studies on pear and could play an important role in pear pollination, as described in strawberry (Hodgkiss et al. 2018). 

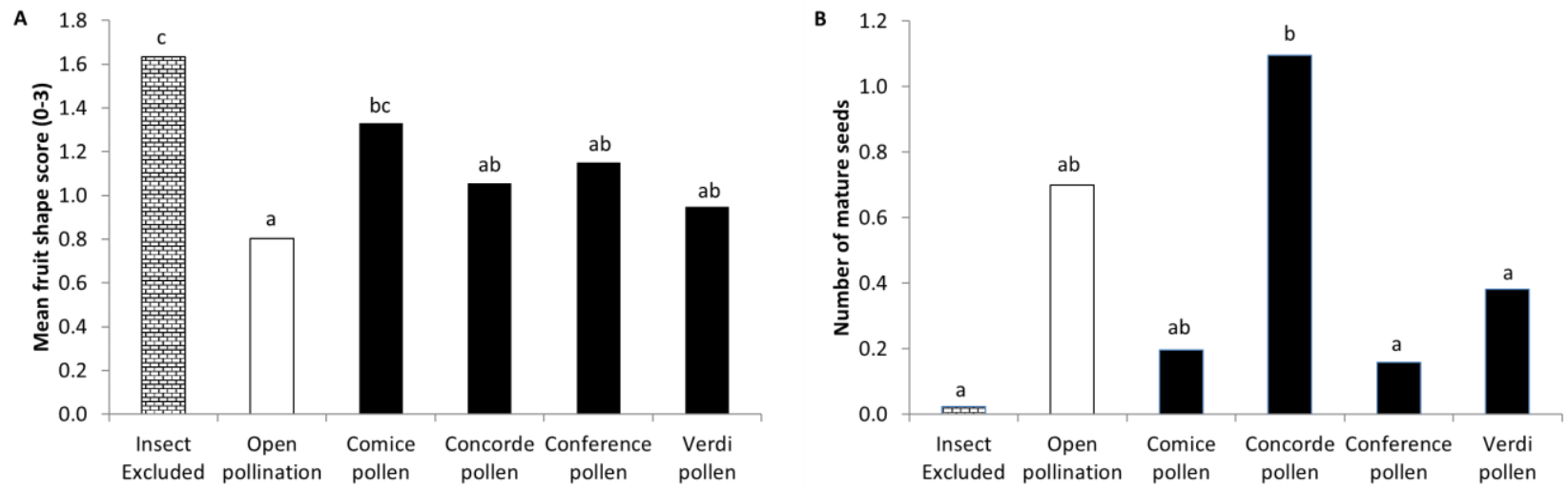

FIGURE 5. Fruit quality measures from Conference flowers open pollinated (by wind and insect visits), insect excluded (wind pollination only) or hand pollinated with either Comice, Concorde, Conference or Verdi pollen. Mean A) fruit shape score ( 0 normal shape, I slight twisting, 2 twisting and unsymmetrical, 3 severely misshapen) and B) number of mature seeds (those which were brown in colour) in the 2016 experiment.

However, we observed that only $25 \%$ of Dipteran visits made contact with the reproductive parts of pear flowers. Diptera, in general, are an under studied group of pollinators in many plants (Orford et al. 2015; Rader et al. 2016).

Bumble bees are considered efficient pollinators of fruit crops due to their speed, morphology and high activity rate in unfavourable weather (Lundberg \& Ranta 1980; Westerkamp 199I). Our surveys recorded relatively low numbers of bumble bees foraging pear flowers (0.I52 visits/flowers/minute), but authors suggest that bumble bees are effective pear pollinators (Calzoni \& Speranza 1996; van den Eijnde 1996; Jacquemart et al. 2006; Zisovich et al. 2012), depositing more pollen grains per pear flower than honey bees (Jacquemart et al. 2006). During periods of poor weather, common during pear flowering, solitary- and bumble-bees forage at lower temperatures than honey bees; even visiting apple flowers under strong wind or light rain (Vicens \& Bosch 2000). This promotes fruit- and seed-set, reducing the proportion of misshapen fruits compared to no pollinators or honey bees alone (Wei et al. 2002; Ladurner et al. 2004). The introduction of commercial bumblebees to support wild insects in early flowering crops may be beneficial in years with poor weather, but needs investigating.

Calzoni and Speranza (1998) demonstrated that honey bee pollinated, self-incompatible, pear achieved higher fruit set, quality and yield if pollinated by bees (vs. no bees). In this study, even though Conference is considered self-compatible, insect pollination was responsible for $\sim 10 \%$ Conference fruit set. Normally each fruit truss can only support up to 4 marketable sized fruits, and there is natural fruit abortion shortly after fruit set, but the quality of the fruits, particularly size and shape, was improved by insect pollination.

Honey bees reportedly visit 8 flowers per minute compared to I4 from the solitary bee Osmia cornuta. In the same study, $O$. cornuta also made more frequent contact with the stigma of pear flowers; almost double (Monzón et al. 2004). In our study, honey bees contacted the flower centre as frequently as solitary bees. However, differences in morphology and behaviour could result in differing pollen transfer efficacy. Although honey bees are recorded as less effective pollinators compared to bumble bee and solitary bee species in several crops (e.g. Willmer et al. 1994), honey bees constituted a significant proportion of the insects visiting pear flowers, in this study, and could be making a significant contribution to pollination of pear in the absence of other groups.

Insect foraging from the orchard boundary revealed more honey bees and fewer bumble bees at $20 \mathrm{~m}$. Hoverflies and other Diptera were more active closer to the orchard edge ( 0 $5 \mathrm{~m}$ ). Our study was comprised of a 'snap-shot' assessment of insect foraging activity; hence, we could have missed other interactions, during blossom. This is a limitation of timed survey approaches. Alternatively, this result may indicate between-guild interactions or optimal foraging distances and requires further study. However, despite this varying activity at distances into the orchards there was no detectable effect on fruit quality.

Our study and others have identified seed set as an important indicator of fruit development that influences fruit dry matter and shape, hence marketability (Brookfield et al. 1996; Volz et al. 1996; Buccheri \& Di Vaio 2005; Matsumoto et al. 2012; Garratt et al. 2014; Garratt et al. 20I6). Pear, generally, has a lower seed set compared to apple (Nyéki \& Soltész I998 a,b). In the majority of our studies the seed set was less than one per fruit. Our results suggest that cross-pollination with another variety could improve seed set in, at least, UK orchards. The low seed set in Conference is due to parthenocarpic fruit development (Jacquemart et al. 2006; Quinet \& Jacquemart 2015). In a Belgium study, no viable (mature) seeds were observed in self- and openpollinated Conference fruits $(0 . I \pm 0 . I$ per fruit $( \pm S E)$, Jacquemart \& Michotte-Van der Aa (2003)). In our study flowers insect- or hand-pollinated with Conference pollen had greater numbers of mature seeds than insect excluded flowers (0.52, 0.22 and 0.01 mature seeds, respectively), and a better shape score (0.90, I.03 and I.64, respectively). Pear flesh differs from that of apple as the cell walls contain small amounts of lignin in the form of brachysclereids (Tao et al. 2009). Higher dry matter may be important for longevity of fruit storage, and better eating quality is a recognised attribute when evaluating quality and flavour for many types of fruit 
including apples (Palmer 2007; Palmer et al. 2010). In addition, pre-harvest dry matter of pears is an indicator of postharvest fruit quality (Travers 20I3). Insect excluded blossoms in this study resulted in fruits with less dry matter than insect visited pears, an indicator of poor fruit development.

Poor pear pollination could result if there is low insect activity, and/or inefficient transfer of pollen, few or the wrong polliniser cultivar, incompatible pollen and/or an asynchronous flowering period with the polliniser. Differences in fruit quality (seed set and resultant shape score) resulted if Conference pear flowers were cross-pollinated with Concorde. Hand pollination of Conference with Concorde pollen resulted in fruits that were heavier and wider than selfpollinated fruits. Interestingly cross-pollinating with Verdi, the polliniser tree planted in the study orchard, did not improve pear fruit quality in this study. As this is a recommended polliniser cultivar for Conference this needs further investigation. Intensive commercial Conference orchards often have no or only one polliniser variety planted, even though at least two compatible (produce sufficient amount of viable and compatible pollen, and flower synchronously) pollinisers/cultivars are recommended for commercial production (Delaplane \& Mayer 2000; Webster 2002). In Belgium, 'Comice' or 'Triomphe de Vienne' are recommended in Conference orchards to achieve good yields (Warnier 2000). Other recommended cultivars for Conference include Williams, Concorde and Passe Crassane (Moriya et al. 2005), and recently several studies have shown that Asian pear varieties can fertilize Conference (Quinet et al. 2016a; Bieniasz et al. 2017).

Consideration should be given to the duration of flowering of the harvested pear cultivar ( $\sim$ I6 days for Conference, NIAB EMR data, 2012-2019) and the interplanted polliniser trees. There needs to be a good degree of overlap of receptive blooms. The overlap of flowering periods between Doyenné du Comice and Conference varied about five days in the Netherlands (van den Eijnde 1996), and between two and ten days in Belgium (Quinet \& Jacquemart 2017). Our study and data from the UK National Fruit Collection in the south-east England have shown that Doyenné du Comice does not synchronously flower with Conference in most years. Hence, this study would suggest that Concorde may be good choice for UK grown Conference, but more data is required to confirm synchronization between these two cultivars.

In conclusion, cross-pollination of pear blossoms, aided by insect visits, are key to the commercial production of pear fruit.

Future research should focus on the delivery of pollen from non-Conference sources to improve the reliability of marketable fruit. Research to test how to provide and incorporate polliniser trees or grafts into modern intensive commercial pear orchards and at what density to ensure economic benefit is needed. A key element would be to decipher which insect guilds play a significant role in pollen transfer and fruit quality, as done, to some extent, in apple (Garratt et al. 2016; Blitzer et al. 2016) and strawberry (Hodgkiss et al., 2018; Martin et al., 2019). In addition, fruit breeding programs should consider the attractiveness of cultivar blossoms to pollinators (as demonstrated in Garratt et al. 2016; Quinet et al. 20I6b).

\section{ACKNOWLEDGEMENTS}

We would like to thank Nigel Stewart (A C Goatham \& Son) for leading the project and we indebted to Oliver Doubleday (G.H. DEAN \& CO. LIMITED), Robert Mitchell (Robert Mitchell Farms), Graham Caspell (NIAB EMR), and Clive Goatham (Flanders Farm) for the use of their orchards. We would also like to thank the Worshipful Company of Fruiterers and Sainsbury's Supermarkets Ltd. for providing the funding for this research, Marzena Lipska for her advice with pollen germination and Stuart Roberts for his help with some of the pollinator identifications.

\section{REFERENCES}

Aizen MA, Garibaldi LA, Cunningham SA, Klein AM (2008) Longterm global trends in crop yield and production reveal no current pollination shortage but increasing pollinator dependency. Current Biology I8:1572-I575.

Aizen MA, Garibaldi LA, Cunningham SA, Klein AM. (2009) How much does agriculture depend on pollinators? Lessons from longterm trends in crop production. Annals of Botany I03:1579-I 588 .

Bieniasz M, Necas T, Dziedzic E, Ondrasek I, Pawłowska B. (2017) Evaluation of pollen quality and self-fertility in selected cultivars of Asian and European pears. Notulae Botanicae Horti Agrobotanici Cluj-Napoca 45(2):375-382.

Biesmeijer JC, Roberts SP, Reemer M, Ohlemüller R, Edwards M, Peeters T, Schaffers AP, Potts SG, Kleukers R, Thomas CD, Settele J, Kunin WE (2006) Parallel declines in pollinators and insect-pollinated plants in Britain and the Netherlands. Science 3I3(5785):35I-354.

Blazek J, Hlusickova I (2006) Seed count, fruit quality and storage properties in four apple cultivars. Journal of Fruit and Ornamental Plant Research I4(2):I5I-I60.

Blitzer EJ, Gibbs J, Park MG, Danforth BN (2016) Pollination services for apple are dependent on diverse wild bee communities. Agriculture, Ecosystems \& Environment 22I:I-7.

Bosch J, Blas M (1994) Effect of over-wintering and incubation temperatures on adult emergence in Osmia cornuta Lat (Hymenoptera, Megachilidae). Apidologie 25(3):265-277.

Boyle RMD, Philogene BJR (1983) The native pollinators of an apple orchard: variations and significance. Journal of Horticultural Science 58(3):355-363.

Brookfield PL, Ferguson IB, Watkins CB, Bowen JH (1996) Seed number and calcium concentrations of 'Braeburn' apple fruit. Journal of Horticultural Science 7I(2):265-27I.

Buccheri M, Di Vaio C (2005) Relationship among seed number, quality, and calcium content in apple fruits. Journal of Plant Nutrition 27(10):I735-1746.

Calzoni GL, Speranza A (1996) Pear and plum pollination: Honey bees, bumble bees of both? Acta Horticulturae 423:83-90.

Calzoni GL, Speranza A. (1998) Insect controlled pollination in Japanese plum (Prunus salicina Lindl.). Scientia Horticulturae 72(3-4):227-237.

Carvalheiro LG, Seymour CL, Veldtman R, Nicolson SW (2010) Pollination services decline with distance from natural habitat even in biodiversity-rich areas. Journal of Applied Ecology 47(4):8I0820.

Carvalheiro LG, Kunin WE, Keil P, Aguirre-Gutiérrez J, Ellis WN, Fox R, Groom Q, Hennekens S, Van Landuyt W, Maes D, Van 
de Meutter F, Michez D, Rasmont P, Ode B, Potts SG, Reemer M, Roberts SPM, Schaminée J, WallisDeVries MF, Biesmeijer JC (2013) Species richness declines and biotic homogenisation have slowed down for NW-European pollinators and plants. Ecology Letters 16:870-878.

Deckers T, Schoofs H (2002). Improvement of fruit set on young pear trees cultivar Conference with gibberellins. Acta Horticulturae 596:735-743

DEFRA (Department for Environment, Food and Rural Affairs) (2016) Agriculture in the United Kingdom 2016. [online] URL: https://www.gov.uk/government/organisations/department-forenvironment-food-rural-affairs/about/statistics.

Delaplane KS, Mayer DF (2000) Crop pollination by bees. Cabi, New York.

FAOSTAT (20I5) FAOSTAT, Production-Crops. [online] URL: http://www.fao.org/faostat/en/\#data/QC.

Free JB (1993) Insect pollination of crops. Academic Press, London. Garibaldi LA, Steffan-Dewenter I, Winfree R, Aizen MA, Bommarco R, Cunningham SA, Kremen C, Carvalheiro LG, Harder LD, Afik O, Bartomeus I (2013) Wild pollinators enhance fruit set of crops regardless of honey bee abundance. Science 339(6I27):1608-I6II.

Garratt MP, Breeze TD, Jenner N, Polce C, Biesmeijer JC, Potts SG (20I4) Avoiding a bad apple: Insect pollination enhances fruit quality and economic value. Agriculture, Ecosystems \& Environment 184:34-40.

Garratt MPD, Breeze TD, Boreux V, Fountain MT, McKerchar M, Webber SM, Coston DJ, Jenner N, Dean R, Westbury DB, Biesmeijer JC (2016) Apple pollination: demand depends on variety and supply depends on pollinator identity. PloS one II(5):e0I53889

Goldway M, Takasaki-Yasuda T, Sanzol J, Mota M, Zisovich A, Stern RA, Sansavini S (2009) Renumbering the S-RNase alleles of European pears (Pyrus communis L.) and cloning the SI09 RNase allele. Scientia Horticulturae II9(4):417-422.

Goodell K, Thomson JD (1996) Comparisons of pollen removal and deposition by honey bees and bumble bees visiting apple. Acta Horticulturae 437:103-108.

Hodgkiss D, Brown MJF, Fountain MT (2018) Syrphine hoverflies are effective pollinators of commercial strawberry. Journal of Pollination Ecology 22:55-66.

Hoehn P, Tscharntke T, Tylianakis JM, Steffan-Dewenter I (2008) Functional group diversity of bee pollinators increases crop yield. Proceedings of the Royal Society B: Biological Sciences 275(I648):2283-229I.

Jacquemart AL, Michotte-Van der Aa A (2003) Tests de parthénocarpie chez les poiriers Pyrus communis L. var. Conférence, Durondeau et Doyenné. Le Fruit Belge 505:170-I73.

Jacquemart AL, Michotte-Van der Aa A, Raspé O (2006) Compatibility and pollinator efficiency tests on Pyrus communis L. cv. 'Conference'. The Journal of Horticultural Science and Biotechnology 8I(5):827-830.

Klein AM, Vaissiere BE, Cane JH, Steffan-Dewenter I, Cunningham SA, Kremen C, Tscharntke T (2007) Importance of pollinators in changing landscapes for world crops. Proceedings of the Royal Society B: Biological Sciences 274(I608):303-313.

Klein AM, Steffan-Dewenter I, Tscharntke T (2003) Fruit set of highland coffee increases with the diversity of pollinating bees. Proceedings of the Royal Society of London. Series B: Biological Sciences 270(I5I8):955-961.

Ladurner E, Recla L, Wolf M, Zelger R, Burgio G (2004) Osmia cornuta (Hymenoptera Megachilidae) densities required for apple pollination: a cage study. Journal of Apicultural Research 43(3):II8-I22.

Lundberg H, Ranta E (1980) Habitat and food utilization in a subarctic bumble bee community. Oikos 35(3):303-3I0.

MAFF (Ministry of Agriculture, Fisheries and Food) (1973) Pears. Her Majesty's Stationary Office, London.

Mallinger RE, Gratton C (20I5) Species richness of wild bees, but not the use of managed honey bees, increases fruit set of a pollinator-dependent crop. Journal of Applied Ecology 52:323330.

Martin CD, Brown MJF, Fountain MT (2019) Varietal and seasonal differences in the effects of commercial bumble bees on fruit quality in strawberry crops Agriculture, Ecosystems and Environment 28I:I24-I33

Martins KT, Gonzalez A, Lechowicz MJ (2015) Pollination services are mediated by bee functional diversity and landscape context. Agriculture, Ecosystems and Environment 200:12-20.

Matsumoto S, Soejima J, Maejima T (2012) Influence of repeated pollination on seed number and fruit shape of 'Fuji' apples. Scientia horticulturae I37:I3I-I37.

Meffe GK (1998) The potential consequences of pollinator declines on the conservation of biodiversity and stability of food crop yields. Conservation Biology, I2:8-I7.

Monzón VH, Bosch J, Retana J (2004) Foraging behavior and pollinating effectiveness of Osmia cornuta (Hymenoptera: Megachilidae) and Apis mellifera (Hymenoptera: Apidae) on 'Comice' pear. Apidologie 35(6):575-585.

Moriya Y, Takai Y, Okada K, Ito D, Shiozaki Y, Nakanishi T, Takasaki T (2005) Parthenocarpy and self- and crossincompatibility in ten European pear cultivars. Journal of the Japanese Society for Horticultural Science 74(6):424-430.

McCullagh P, Nelder JA (1989) Generalized Linear Models. 2nd Edition. Chapman and Hall/CRC. Pp 532. Nyéki J, Soltész M (1996) Floral biology of temperate zone fruit trees and small fruits. Akadémiai Kiadó, Budapest.

Nyéki J, Soltész M (1998a) The variation of seed content of fruits in pear varieties, also as function of different conditions of fertilization, as open pollination, natural autogamy and allogamy. Acta Horticulturae 475:237-250

Nyéki J, Soltész M (1998b) Fruit set of pear varieties by open pollination at sites of different ecological conditions. Acta Horticulturae 475:355-366.

Orford KA, Vaughan IP, Memmott J (2015) The forgotten flies: the importance of non-syrphid Diptera as pollinators. Proceedings of the Royal Society B: Biological Sciences 282(I805):20I42934.

Palmer JW (2007) Apples and kiwifruit, can we learn from each other? Acta Horticulturae 753:359-368.

Palmer JW, Harker FR, Tustin DS, Johnston J (2010) Fruit dry matter concentration: a new quality metric for apples. Journal of the Science of Food and Agriculture 90(I5):2586-2594.

Potts SG, Biesmeijer JC, Kremen C, Neumann P, Schweiger O, Kunin WE (2010) Global pollinator declines: trends, impacts and drivers. Trends in Ecology and Evolution, 25:345-353.

Pywell RF, Warman EA, Carvell C, Sparks TH, Dicks LV, Bennett D, Wright A, Critchley CNR, Sherwood A (2005) Providing foraging resources for bumble bees in intensively farmed landscapes. Biological Conservation I2I(4):479-494.

Quinet M, Jacquemart AL (2015) Difference between Pollination and Parthenocarpy in the 'Conference' Pear Production. Acta Horticulturae 1094:359-366. 
Quinet M, Jacquemart AL (2017) Cultivar placement affects pollination efficiency and fruit production in European pear (Pyrus communis) orchards. European Journal of Agronomy 91:84-92.

Quinet M, Mabeluanga T, Moquet L, Jacquemart AL (2016a) Introduction of new tools to improve pollination in European pear orchards. Scientia Horticulturae 213:5-I2.

Quinet M, Warzée M, Vanderplanck M, Michez D, Lognay G, Jacquemart AL (2016b) Do floral resources influence pollination rates and subsequent fruit set in pear (Pyrus communis L.) and apple (Malus $\boldsymbol{X}$ domestica Borkh) cultivars? European Journal of Agronomy 77:59-69.

Rader R, Bartomeus I, Garibaldi LA, Garratt MP, Howlett BG, Winfree R, Cunningham SA, Mayfield MM, Arthur AD, Andersson GK, Bommarco R (2016) Non-bee insects are important contributors to global crop pollination. Proceedings of the National Academy of Sciences II3(I):I46-I5I.

Sakamoto D, Hayama H, Ito A, Kashimura Y, Moriguchi T, Nakamura Y (2009) Spray pollination as a labor-saving pollination system in Japanese pear (Pyrus pyrifolia (Burm. f.) Nakai): development of the suspension medium. Scientia horticulturae II9(3):280-285.

Santos GA, Batugal PA, Othman A, Baudouin L, Labouisse JP (I996) Manual on standardized research techniques in coconut breeding. International Plant Genetic Resources Institute (IPGRI), Rome.

Sánchez-Bayo F. Wyckhuys KAG (2019) Worldwide decline of the entomofauna: a review of its drivers. Biological Conservation, 232:8-27.

Shaw B, Brain P, Wijnen H, Fountain MT (2019) Implications of sub-lethal rates of insecticides and daily time of application on Drosophila suzukii lifecycle. Crop Protection, I2I:I82-I94.

Shivanna KR, Rangaswamy NS (2012) Pollen Biology: A Laboratory Manual. Springer Science \& Business Media, 6 Dec 2012 - Technology \& Engineering - pp. II9.

Stern RA, Goldway M, Zisovich AH, Shafir S, Dag A (2004) Sequential introduction of honey bee colonies increases crosspollination, fruit-set and yield of 'Spadona' pear (Pyrus communis L.). The Journal of Horticultural Science and Biotechnology 79(4):652-658.

Stern RA, Sapir G, Shafir S, Dag A, Goldway M (2007) The appropriate management of honey bee colonies for pollination of
Rosaceae fruit trees in warm climates. Middle Eastern and Russian Journal of Plant Science and Biotechnology I(I):I3-I9.

Tao S, Khanizadeh S, Zhang H, Zhang S (2009). Anatomy, ultrastructure and lignin distribution of stone cells in two Pytus species. Plant Science 176:4I3-4I9.

Travers S (2013) Dry matter and fruit quality: manipulation in the field and evaluation with NIR spectroscopy. $\mathrm{PhD}$ thesis. Department of Food Science Aarslev University, Denmark.

Van den Eijnde J (1996) Pollination of pear by bumble bees (Bombus terrestris L.) and honey bees (Apis mellifera L.). Acta Horticulturae 423:73-78

Vicens N, Bosch J (2000) Weather-dependent pollinator activity in an apple orchard, with special reference to Osmia cornuta and Apis mellifera (Hymenoptera: Megachilidae and Apidae). Environmental Entomology 29(3):4I3-420.

Visser T, Verhaegh JJ (1987) The dependence of fruit and seed set of pear and apple on the number of styles pollinated. Gartenbauwissenschaft 52:13-16.

Volz RK, Tustin DS, Ferguson IB (1996) Pollination effects on fruit mineral composition, seeds and cropping characteristics of 'Braeburn' apple trees. Scientia horticulturae 66(3-4):I69-I80.

VSN International (2015). Genstat for Windows I8th Edition. VSN International, Hemel Hempstead.

Warnier O (2000) Quel est l'intérêt d'une pollinisation croisée pour la poire 'Conférence'? Le Fruit Belge 484:47-50.

Webster AD (2002) Factors influencing the flowering, fruit set and fruit growth of European pears. Acta Horticulturae 596:699-709.

Wei S-G, Wang R, Smirle MJ, Xu H-L (2002) Release of Osmia excavata and Osmia jacoti (Hymenoptera: Megachilidae) for apple pollination. Canadian Entomology I34:369-380.

Westerkamp C (I99I) Honey bees are poor pollinators-why? Plant Systematics and Evolution 177(I-2):71-75.

Willmer PG, Bataw AAM, Hughes JP (1994) The superiority of bumble bees to honey bees as pollinators: insect visits to raspberry flowers. Ecological Entomology I9(3):27I-284.

Zisovich AH, Goldway M, Schneider D, Steinberg S, Stern E, Stern RA (2012) Adding bumble bees (Bombus terrestris L., Hymenoptera: Apidae) to pear orchards increases seed number per fruit, fruit set, fruit size and yield. The Journal of Horticultural Science and Biotechnology 87(4):353-359. 